\title{
The mediating effect of entrepreneurial marketing in the relationship between environmental turbulence and dynamic capability with sustainable competitive advantage: An empirical study in Indonesian MSMEs
}

\author{
Umu Khouroh $^{a^{*}}$, Achmad Sudiro $^{a}$, Mintarti Rahayu ${ }^{a}$ and Nur Khusniyah Indrawatia
}

\begin{abstract}
${ }^{a}$ Faculty of Economics and Business, Brawijaya University, Malang, Indonesia
\section{CH R O N I C L E}

\section{Article history:}

Received: June 252019

Received in revised format: July

292019

Accepted: September 4, 2019

Available online:

September 4, 2019

Keywords:

Environmental turbulence

Dynamic capability

Entrepreneurial marketing

Sustainable competitive advantage

\section{A B S T R A C T}

The aim of this study was to examine the role of entrepreneurial marketing as a mediating variable in the relationship between environmental turbulence and dynamic capability with sustainable competitive advantage. This study involved 130 craft industries in Malang Regency, Malang City, and Batu City, East Java, Indonesia. Application of loading factor followed by SEM-PLS developed a model showing how environmental turbulence and dynamic capability influence on entrepreneurial marketing which consequently leads to differentiation and performance improvement which are the established indicators of sustainable competitive advantage for the firms. The model was empirically validated using model fit indices and was found satisfactory. The findings show that environmental turbulence did not have any significant relationship with a sustainable competitive advantage. Dynamic capability had a significant relationship with a sustainable competitive advantage. Entrepreneurial Marketing mediates the relationship between environmental dynamic capabilities with sustainable competitive advantage. The analysis shows that highly dynamic capability and entrepreneurial marketing tends to highly sustainable competitive advantage. It indicated that dynamic capability and entrepreneurial marketing offer systematic model for supporting Micro, Small, and Medium Enterprises (MSMEs) to build a well-maintained environment and sustainable competitive advantage.
\end{abstract}

\section{Introduction}

Micro, Small, and Medium Enterprises (MSMEs) play important and strategic role in driving national economy, especially from the perspective of job opportunity and income source for the poor, income distribution, and poverty reduction (Tambunan, 2010). Until 2017, MSME in Indonesia dominated the business units up to $99.9 \%$ of a total of 57.89 million. Contribution of MSMEs to gross domestic product (GDP) reached 57.65 percent, employment reached 96.9 percent, and nonoil-and-gas export reached 15.68 percent (Bank Indonesia, 2018). Industrial era makes the challenges faced by MSMES harder. Adaptation ability becomes a tool to face the changes that occur in external environment. Some changes, such as globalization effect, changes of information technology and regulations, are the changes that potentially cause turbulence in the environment (Hitt et al., 1998). This change affects the relevance of strategy and achievement of competitive advantage. Environmental turbulence is characterized by changes that are dynamical and complex, quick and unpredictable, and cause uncertainty (Volberda \& Bruggen, 1997; Eisenhardt \& Brown, 1998). The characteristics of changes trigger and demand business to take strategic steps and adjust business strategies. The results of some studies show that environmental turbulence is able to support competitive strategies that result in achievement of competitive advantage (Ward \& Duray, 2000; Kuivalainen et al., 2009). The research findings are different from those of other studies that state that environmental turbulence has negative effect on performance (Li \& Atuahene-Gima, 2001; Lin \& Germain, 2003; Power \& Reid, 2005).

\footnotetext{
* Corresponding author.

E-mail address: umukhouroh@yahoo.com (U. Khouroh) 
The basic changes of business environment that cause turbulence also cause the resources and core capabilities of companies to be obsolete and irrelevant. MSMEs are demanded to adjust business strategies, adjust and improve basic capabilities by improving the dynamic capabilities. Teece et al. (1997) suggested that companies should implement continuous adjustment, reconfigure and renew their resources and capabilities to overcome the environmental changes that currently becomes a universal concept of dynamic capabilities. Dynamic Capability View (Teece et al., 1994; Grant, 1996; Teece et al., 1997; Teece, 2016) emphasizes on internal and external competence exploitation in responding to changing environment. The development of studies about dynamic capability gives different and sequential definition that creates confusion of meaning and use of its construction (Barreto, 2010; Stefano et al., 2010; Helfat \& Winter, 2011). Some scholars believe that dynamic capability is the key of competitive advantage (Ambrosini et al., 2009; Helfat \& Peteraf, 2009; Teece, 2007; Teece et al., 1997) while several others argue that dynamic abilities do not manifest heterogeneity characteristics, so it cannot be a source of competitive advantage (Arend \& Bromiley, 2009; Eisenhardt \& Martin, 2000) and the role of dynamic capability is limited (Zott, 2003) and indirect (Wang \& Ahmed, 2007).

Tambunan (2008) explains three facts related to MSMEs in Indonesia, namely: productivity, competitiveness and low performance. Statistics Indonesia (2015) also identified the obstacles and problems of MSMEs in Indonesia including: 1) Human Resources, 2) Financing; 3) Marketing, 4) Management and Technology; and 5) Institutional. One of the ways to say the marketing challenges and obstacles for MSMEs is by Entrepreneurial Marketing (EM) approach. Entrepreneurship approach in marketing becomes a solution to answer the challenges and problems especially marketing in new and small enterprises (Kraus et al., 2009). The main support of EM is the emphasis on the effort to adapt to suitable marketing form for SMEs and recognize the important role of entrepreneurs in each marketing activity (Stokes, 2000). The concept of EM came from a work Lumpkin \& Dess (1996) that discusses about Entrepreneurship Orientation (EO) and Market Orientation (MO) (Kohli \& Jaworski, 1990). The two constructions have become the central theme in theories and studies on general management (Kirca et al., 2005; Baker \& Sinkula, 2009; Rauch et al., 2009; Kevin \& Wang, 2011), have relationship with company performance (Rauch et al., 2009; Kirca et al., 2005; Zahra \& Garvis, 2000) the main theme in scientific research (Kropp et al., 2006; Cadogan et al., 2009; Zahra \& Garvis, 2000; Knight \& Kim, 2009).

To give valuable scientific insight and broad managerial interest, the study at least gives empirical roofs to fill the gap and limitedness of studies on the effect of environmental turbulence, dynamic capability, and EM in developing countries. At least there are three important things to broaden the existing literature.

First, previous studies did not consider how high the activities of EO and MO could complete each other to achieve competitive advantage. Literature on strategic orientation shows that company ability to implement activities of EO and MO at the same time could bring greater benefits because the two orientations have advantage to reduce potential weakness of each other (Hakala, 2011; Hult \& Ketchen, 2001). Thus, increasing the simultaneous implementation of these two orientations enables companies to produce greater synergy between entrepreneurial abilities and market-oriented competencies to improve performance (Li \& Atuahene-Gima, 2001). The empirical facts show that there is a significant permanent relationship between $\mathrm{MO}$ and EO and the two directly influence the success of organization (Stokes, 2000). EM unites the key aspects of development of thinking and marketing practice in field of entrepreneurship to be one comprehensive construction (Kraus et al., 2009). EM is an integrative construction to conceptualize marketing in the era of changes, complexity, chaos, contradiction, and decrease of resources, and it is also one of the ways to manifest itself differently as a mature and growing company (Morris et al., 2002). However, although there is a potential insight from the strategy for theoretical development and practice of small enterprises, the effect owned by the increase of EM activities on SMEs performance was less studied.

Second, researches that studies about how companies implement the capability of EO and MO did not examine the main contingency factors, such as the presence of other factors like resources and environmental condition, that could shape the success of strategies and, at the same time, focus on the improvement of activities of both EO and MO. Literature shows that SMEs could effectively fight to improve higher performance because of limited resources and environmental changes (Morris et al., 2002). While the dominant approach in literature of small enterprises is to review the effect only on the main effect or two-way contingency effect model (Lumpkin \& Dess, 2001; Knight \& Kim, 2009), we modelled the high effect of EO and MO together in EM construct, dynamic capability and environmental turbulence in competitive advantage in integrated model. The approach refers to organization configuration literature (Meyer et al., 1993; Thomas, \& Snow, 1993; Short et al., 2008) with the argument that elements of EM activities, dynamic capabilities and environmental conditions can be combined to improve company performance.

Third, given that most studies on dynamic capabilities and EO-MO are based on developed economies, the findings of this study can be generalized to developing economies. Although there are several studies on dynamic capabilities and EO-MO from developing countries, many of them are based on samples from Asia (mainly China) and some on samples from Central and Eastern European countries. Interestingly, very few studies focus on SMEs in developing countries for constructing dynamic capabilities (Parida, 2008) and EO and MO (Hoskisson et al., 2000). Thus, given the importance of context in the development of theory (Hoskisson et al., 2000; Wright et al., 2005; Parida, 2008), we examine EO and MO activities and dynamic capabilities in the settings of developing southeast Asia to find a useful extension of existing literature, and provide the relationship between orientation company strategic and business success. 


\section{Literature Review and Hypotheses}

Fig. 1 presents the conceptual model for the study and the following section presents the theoretical and hypotheses developed.

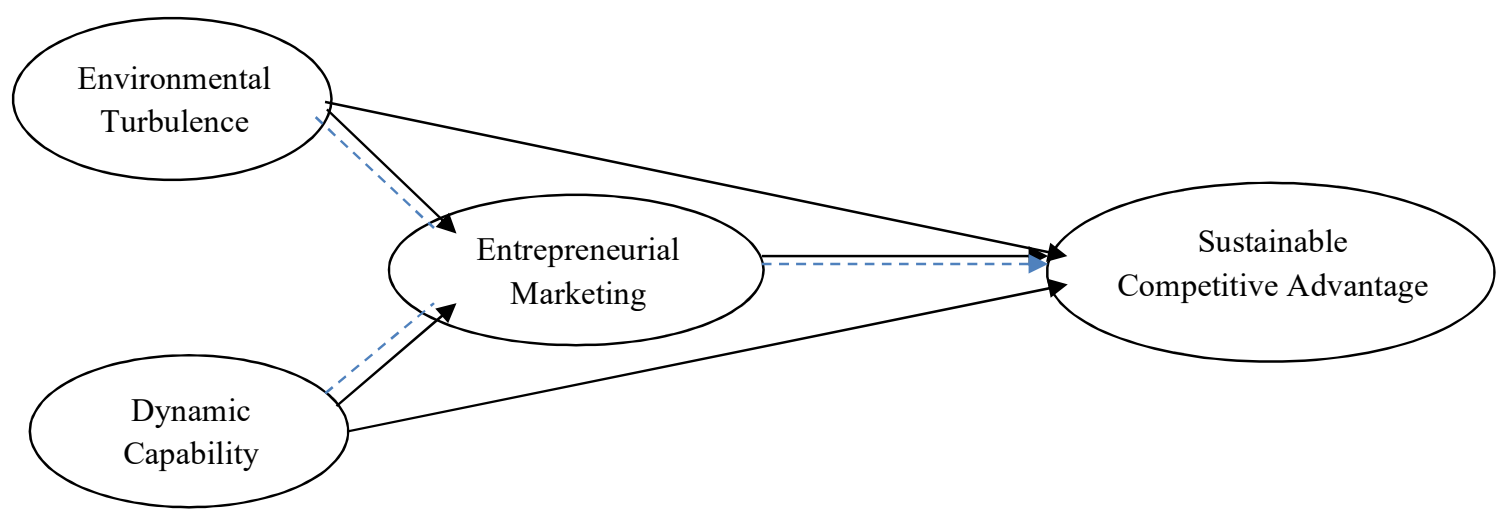

Fig.1. Conceptual Research Framework

\subsection{Environmental Turbulence and Sustainable Competitive Advantage}

In the perspective strategic management, environment is a contextual factor that has effect on company performance. Environment is physical and social factor that has direct effect on personal behavior of decision making in organization (Duncan, 1972). May scholars classify the characteristics of environment in stability/dynamic, simplicity/complexity, and munificence /hostility (Dess \& Beard, 1984; Mintzberg, 1984; Tan \& Litschert, 1994). Companies need to be aware of environmental conditions that cause turbulence. Environmental turbulence is related to the increase of changes and drastic characteristics of many changes that make it harder to identify the causes or predict the result of competitive initiative with adequate certainty (Bower \& Christensen, 1995; D’Aveni \& Gunther, 1995).

Through certain development ways, companies can obtain competitive advantage within certain period. Ward et al. (1995) show that environmental turbulence affects performance. When environmental changes are difficult to predict, organizations have to be able to adapt quickly to survive and that turbulence is new normal mechanism to overcome (Gordon, 2000). The small form and organization structure of SME facilitate SME to immediately adjust themselves to various environmental changes to accelerate the achievement of competitive advantage. Based on that, a hypothesis for the study is constructed as follows:

H1: Higher environmental turbulence will improve sustainable competitive advantage.

\subsection{Dynamic Capability and Sustainable Competitive Advantage}

Excellent business strategies are generally based on excellent resources and capabilities. Environmental changes allegedly make the excellent resources and capabilities obsolete and irrelevant. Therefore, companies have to improve their competitiveness by developing and together finding new sources of technology and skills that can lead to formation of new company structure (Hamel et al., 1989; Prahalad \& Hamel, 1990) through the ability to renew resources and dynamic capability. Teece et al. (1997) showed that dynamic capability is the company's ability to integrate, develop, and configure internal and external competences to quickly overcome environmental changes while dynamic capability is in the company process that can change current position and causes some effects on company performance and competitive advantage, as well as new position and ways. Companies need to develop and implement dynamic capability to maintain competitive advantage in changing and complex external environment (Ambrosini et al., 2009). Dynamic capability has significant effect on competitive advantage and is able to affect Valuable, Rare, non-Imitated, and Non-substituted resources (VRIN) of SMEs to achieve competitive advantage in quickly changing business environment (Adeniran, 2012). MSMEs have to adjust their basic capability as a part of company activities to be able to improve their competitiveness to achieve competitive advantage. Based on the explanation above, a hypothesis for the study is constructed as the follow,

$\mathbf{H}_{2}$ : Higher dynamic capability will increase sustainable competitive advantage.

\subsection{Entrepreneurial Marketing and Sustainable Competitive Advantage}

Competition is a continuous battle among companies to achieve comparative advantage of resources that finally will result in sustainable competitive advantage in market. Consistent with competition dynamic in theory of R-A, marketing can facilitate the company ability to create new resources and improve productivity of the existing resources (a) through various leverage approaches and (b) by developing innovations in new combination forms of resources (Morris et al., 2002). 
Hunt and Morgan (1996) stated that companies can avoid and surpass their competitors by managing their existing resources better and/or by acquisition, imitation, substitution, or innovation of market. Basically, EM is considered as critical resources that offer companies an ability to explore the opportunities to develop entrepreneurship and exploit the existing product market competition (Baker \& Sinkula, 2009; Bhuian et al., 2005; Kohli \& Jaworski, 1990). It also has relationship with company performance (Rauch et al., 2009; Kirca et al., 2005; Zahra \& Garvis, 2000). Many companies adopt EM as a strategy to make market niche to create defensive position and maintain competitive advantage (Thomas et al., 2013). Therefore, companies need to adopt MO and carry out their EO as mutually important matters in current dynamic market; being proactive in market driving and being market driver based on excellent market to achieve higher performance (Morris et al., 2002). EM offers competitive advantage for MSMEs. The characteristics and strategies of EM help MSMEs survive and succeed in business. Kocak and Abimbola (2009) showed that organization structure, entrepreneur process, as well as MO and learning are important materials for the success of starting business and have practical relevance for entrepreneurs and MSMEs in developing countries. Based on the explanation, a hypothesis for the study is constructed as the follows:

H3: Higher entrepreneurial marketing will improve sustainable competitive advantage.

\subsection{Environmental Turbulence, Dynamic Capability, Entrepreneurial Marketing and Sustainable Competitive Advantage}

There are various challenges and demands that MSMEs formulate their competitive strategies appropriately when companies face environmental turbulence. Some studies show that environmental turbulence has negative effect on achievement of competitive advantage (Li \& Atuahene-Gima, 2001; Power \& Reid, 2005; Lin \& Germain, 2003). Changes in the environment also make change resources obsolete and irrelevant that requires companies to adjust their capabilities. Some scholars argue that dynamic abilities does not manifest heterogeneity characteristics, so it cannot be a source of competitive advantage (Arend \& Bromiley, 2009; Eisenhardt \& Martin, 2000) and the role of dynamic capability is limited (Zott, 2003) and indirect (Wang \& Ahmed, 2007). One of the ways to overcome negative environmental effect and enhance the role of dynamic capabilities in achieving competitive advantage are by implementing EM that is an integrated construct for conceptual marketing in the era of changes, complexity, chaos, contradiction, and reduction of resources (Morris et al., 2002). For MSMEs that face marketing obstacles, the challenge of environmental turbulence and limited resources in achievement of competitive advantage needs an approach that combines the elements of entrepreneurship and marketing summarized in the concept of EM. Marketing approach for MSMEs is not suitable with the existing theory, successful MSMEs can utilize the unique benefit of their "smallness". The actual marketing of MSMEs are EM marked by various factors including inherently informal, simple, and random approach (Carson, 1985). EM is a result of various factors such as: small size of business, limitedness of business and marketing, the entrepreneur's influence; and lack of formal organization system or formal communication system, and even there is no system at all in terms of marketing (Carson, 1990). The approach tends to be responsive and reactive to competition and opportunistic characteristic, highly depends on network, has opportunity to produce social capital, the network facilitates formation of customer contact where mouth-to-mouth recommendation is facilitated by the use of relationship among organization network and personal contact network (Jones \& Rowley, 2011). Some scholars state that marketing has many to offer to entrepreneurship studies (Murray et al., 2011; Murray, 1981) and, on the contrary, entrepreneurship can view marketing as the main function of company that includes innovation and creativity (Collinson \& Shaw, 2001). Empirical evidence show that there is significant correlation between company marketing and EO, the two are broadly responsible for company success (Miles, 1991).

The result of some studies show that EM is affected by environmental turbulence (Morris et al., 2002; Davis \& Morris, 1991; Kam-Sing Wong, 2014; Crema et al., 2014). Environmental turbulence supports companies to develop an ability to overcome risks and to see opportunities in market, to develop momentum and innovative ability to take the opportunities and to overcome the risks and uncertainty the turbulence provides, and to channel and utilize internal efforts to achieve the goals to change opportunities into benefits (Morris et al., 2002; González-Benito et al., 2009). Other studies also show that marketing becomes the key competence of entrepreneurship and it is very important for the sustainability and development of small enterprises. Implementation of EO and MO in EM strategy affects performance and competitive advantage (Miles \& Darroch, 2006; Becherer et al., 2012; Thomas et al., 2013; Kocak \& Abimbola, 2009; Mort et al., 2012) Meanwhile, companies have to improve their competitiveness by developing and mutually finding new sources of technology and skills that can lead to formation of new company structure (Hamel et al., 1989; Prahalad \& Hamel, 1990) through the ability to renew resources and dynamic capability. Borch and Madsen (2007) stated that dynamic capabilities are very important for SME entrepreneurial positions and have a significant positive impact on creativity-proactive strategies and risk-growth-oriented strategies. Company entrepreneurship is viewed as an integrated search of opportunities and profits that give new business concept that is unique and valuable. Meanwhile, there is a need to see the proofs and how companies give supplement to available resources and combine new resources to support the allegation that EM is the mediator of relationship between environmental turbulence and dynamic capability with sustainable competitive advantage of MSMEs. Based on the explanation above, the following hypotheses are proposed.

H4a: Entrepreneurial marketing mediates the effect of environmental turbulence on the improvement of sustainable competitive advantage. 
H4b: Entrepreneurial marketing mediates the effect of dynamic capability on the improvement of sustainable competitive advantage.

\section{Research Methodology}

\subsection{Research Design}

The study was involved multi-industrial survey on micro, small and medium enterprises (MSMEs) of creative economy in Malang Raya East Java Indonesia. The choice of Malang Raya for the study was suitable because of some reasons: 1) Malang City was established as one of the 10 creative cities in Indonesia; 2) Malang Raya is a leading tourist destination in East Java with branding of Shining Batu, Beautiful Malang, and Heart of East Java (Malang Regency) and becomes the supporting area of Bromo-Tengger-Semeru that is a national priority destination; 3) Creative economy business becomes the support of tourism sector development.

\subsection{Data Collection}

The sampling frame was the directory of craft MSMEs provided by Department of Cooperatives and SME and Department of Industry and Trade. The directory gave names, address, and phone address of companies. The reasons for choosing craft sub-sector as the research object were: 1) It was one of the largest units in field of creative economy business; 2) It was one of the largest employment contributors in field of creative economy business; 3) It was one of the largest contributors to added value of creative economy; 4) It was one of the products of creative economy mostly consumed by the people; 5) The number of craft enterprises in Malang City was 32.5\%, Malang City 60.4\%, and Batu City $29.4 \%$ of total enterprises in each region. As in the previous studies in developing countries (Li \& Atuahene-Gima, 2001), data were collected in site because mail and electronic mail system less developed. A number of $192 \mathrm{craft}$ SME were identified and agreed to be interviewed. Finally, the total responses that could be used were obtained reached to 130 enterprises representing the level of response of $49.4 \%$.

The questionnaire consists of two parts. The first part of the questionnaire includes a demographic section related to respondents' of the company. The second part consists of 13 indicators: environmental turbulence ( 2 dimensions), dynamic capability (3 dimensions), entrepreneurial marketing ( 7 dimensions), and competitive advantage ( 4 dimensions). The sevenpoint Likert scale was used to measure the three categories of the construct, the scale from "1" strongly disagrees with "7" strongly agree. The seven-point Likert scale is a valid and appropriate measurement because many previous studies have used seven scales. In this study, the dimensions of environmental turbulence are measured by adapting the indicators suggested by Volberda and van Bruggen (1997). The dynamic capability dimensions were adapted from Li and Liu (2014), the entrepreneurial marketing dimensions were adapted from Becherer et al. (2012) and sustainable competitive advantage dimensions were adapted from Porter (1990), Barney (1991) and Chen et al. (2006).

\subsection{Description of Respondents}

The demographic distribution of respondents is presented in Table 1. The respondents have been categorized on the basis of gender, age and education. We find that most of the respondents have age $>40$ years with undergraduate education level.

Table 1

Respondent Profile

\begin{tabular}{|c|c|c|c|c|c|c|c|c|}
\hline \multicolumn{3}{|l|}{ Sex } & \multicolumn{3}{|c|}{ Age } & \multicolumn{3}{|c|}{ Education } \\
\hline Distribution & $\mathbf{N}$ & $\%$ & Distribution & $\mathbf{N}$ & $\%$ & Distribution & $\mathbf{N}$ & $\%$ \\
\hline Male & 45 & 34.6 & $<30$ years & 21 & 16.1 & Up to Junior High School & 20 & $15.4 \%$ \\
\hline Female & 85 & 65.4 & $30-39$ years & 32 & 24.6 & Senior High School & 36 & $27.7 \%$ \\
\hline & & & $40-49$ years & 45 & 34.6 & Diploma & 10 & $7.7 \%$ \\
\hline & & & $50-59$ years & 24 & 18.5 & Undergraduate & 57 & $43.8 \%$ \\
\hline & & & $>60$ years & 8 & 6.2 & Postgraduate & 7 & $5.4 \%$ \\
\hline
\end{tabular}

The type of business period, classification and number of workers activity being carried by the respondent units is shown in Table 2.

Table 2

Business Profile

\begin{tabular}{|c|c|c|c|c|c|c|c|c|}
\hline \multicolumn{3}{|c|}{ Period of Business } & \multicolumn{3}{|l|}{ Business Classification } & \multicolumn{3}{|c|}{ Number of Workers } \\
\hline Distribution & $\mathbf{N}$ & $\%$ & Distribution & $\mathbf{N}$ & $\%$ & Distribution & $\mathbf{N}$ & $\%$ \\
\hline$\leq 10$ years & 94 & 72.31 & Micro (up to 300 million rupiahs) & 107 & 82.31 & Micro (1-3 persons) & 8 & 6.15 \\
\hline $10-19$ years & 23 & 17.69 & Small ( 300 million $\leq 2.5$ billion rupiahs) & 23 & 17.69 & Small (4-19 persons) & 122 & 93.85 \\
\hline $20-29$ years & 6 & 4.62 & & & & & & \\
\hline$\geq 30$ years & 7 & 5.38 & & & & & & \\
\hline
\end{tabular}




\section{Data Analysis}

To test the developed model, we used partial least square (PLS) approach. PLS is the second-generation multivariate technique that simultaneously evaluates model of measurement of relationship between suitable constructions and indicators and structural model that aims to minimize variance error (Hair et al., 2012; 2013).

\subsection{Measurement Model (Outer Model)}

The outer model testing aims to describe the relationship between dimension blocks and their latent variables. Outer models are used to test the construct validity and reliability. In the PLS method using Warp-PLS 6.0 software to analyze this measurement model there are three criteria, namely convergent validity, discriminant validity and construct reliability. Convergent validity is to what extent some items are suitable to measure the same concept. Discriminant validity is performed to ensure the value of the construct correlation with the dimensions of measurement is greater than the other constructs. Composite reliability testing aims to test the reliability of a construct. As suggested by Hair et al., (2013), we used factor loading and Average Variance Extracted (AVE) to assess convergent validity, Fornell-Larcker Criterion to assess discriminant validity and composite reliability to test the reliability of a construct. The suggested value to load was determined factor loading on $>$ 0.6 , AVE had to be $>0.5$, the square root AVE of each construct was greater than the correlation value between constructs and other constructs in the model, and CR had to be $>0.7$. We used the method suggested in literature of PLS that was repeated indicator approach by modelling the second-order factor in PLS analysis.

Table 3

Measurement Model

\begin{tabular}{|c|c|c|c|c|}
\hline Construct & Indicator & $\begin{array}{l}\text { Loading Fac- } \\
\text { tor }\end{array}$ & AVE & $\mathbf{C R}$ \\
\hline \multirow[t]{2}{*}{ Environmental Turbulence (ET) } & Environmental Dynamism & 0.804 & 0.647 & 0.786 \\
\hline & Environmental Complexity & 0.804 & & \\
\hline \multirow[t]{3}{*}{ Dynamic Capability (DC) } & Strategic-Sense Making Capability & 0.920 & 0.850 & 0.944 \\
\hline & Timely Decision-Making Capability & 0.921 & & \\
\hline & Change Implementation Capability & 0.925 & & \\
\hline \multirow[t]{7}{*}{ Entrepreneurial Marketing (EM) } & Proactive & 0.885 & 0.760 & 0.957 \\
\hline & Opportunity-Driven & 0.877 & & \\
\hline & Risk-Taking Orientation & 0.795 & & \\
\hline & Innovation-Focus & 0.858 & & \\
\hline & Customer Intensity & 0.897 & & \\
\hline & Resources-Leveraging & 0.920 & & \\
\hline & Value Creation & 0.865 & & \\
\hline \multirow[t]{4}{*}{ Sustainable Competitive Advantage (SCA) } & Differentiation & 0.835 & 0.755 & 0.925 \\
\hline & Value, Rare, Non-Imitable, Non-Substitution & 0.845 & & \\
\hline & Management, Innovative, Image & 0.947 & & \\
\hline & Performance & 0.843 & & \\
\hline
\end{tabular}

Notes: $\mathrm{AVE}=$ Average Variance Extracted; $\mathrm{CR}=$ Composite Reliability

\section{Table 4}

Correlations among 1. vs. with sq. rts. of AVEs

\begin{tabular}{lccc}
\hline Construct & ET & DC & EM \\
\hline Environmental Turbulence (ET) & 0.804 & 0.272 & 0.325 \\
Dynamic Capability (DC) & 0.272 & 0.922 & 0.827 \\
Entrepreneurial Marketing (EM) & 0.325 & 0.827 & 0.67 \\
Sustainable Competitive Advantage (SCA) & 0.267 & 0.652 & 0.872 \\
\hline
\end{tabular}

Note: Square roots of average variances extracted (AVEs) shown on diagonal.

\subsection{Structural Model and Overall Model}

To evaluate the strength of structural model prediction, we calculated $\mathrm{R}^{2} . \mathrm{R}^{2}$ shows the amount of variances explained by exogenous variables (Barclay et al., 1995). The limitation of $\mathrm{R}^{2}$ value is classified into three categories: 0.67 means substantial/high; 0.33 means moderate; and 0.19 means low (Chin, 1998). The result of $\mathrm{R}^{2}$ value shows that environmental turbulence and dynamic capability variable had high ability in explaining the changes of EM variable. While environmental turbulence, dynamic capability, EM had moderate ability (48.4\%) in explaining the changes of sustainable competitive advantage.

Table 5

Value of Determination Coefficient (R-Square $\left(\mathrm{R}^{2}\right)$

\begin{tabular}{lccc}
\hline Variable & R-Square $\left(\mathrm{R}^{2}\right)$ & Adjusted R-Square & Description \\
\hline Entrepreneurial Marketing (EM) & 0.700 & 0.695 & High \\
Sustainable Competitive Advantage (SCA) & 0.495 & 0.484 & Moderate \\
\hline
\end{tabular}




\subsection{Goodness of Fit Test (Fit Model and Quality Indices)}

Table 6 shows the result of model suitability test obtained from research model by referring to the result of study, the accepted value limitation, and ideal value of each model quality dimension. The result of general result output shows that all of model quality dimensions was within ideal value or accepted so the research model was stated as a good model (fit) because the required provisions were satisfied. Therefore, it can be concluded that the model proposed and analyzed in the study was supported by data

\section{Table 6}

Goodness of Fit Test (Fit Model and Quality Indices)

\begin{tabular}{lll}
\hline Fit Model and Quality Indices & Computation Result & Probability \\
\hline Average path coefficient (APC) & 0.339 & $\mathrm{P}<0.001$ \\
Average R-squared (ARS) & 0.598 & $\mathrm{P}<0.001$ \\
Average adjusted R-squared (AARS) & 0.590 & $\mathrm{P}<0.001$ \\
Average block VIF (AVIF) & 1.941 & acceptable if $\leq 5$, ideally $\leq 3.3$ \\
Average full collinearity VIF (AFVIF) & 2.515 & acceptable if $\leq 5$, ideally $\leq 3.3$ \\
Tenenhaus GoF (GoF) & 0.671 & small $\geq 0.1$, medium $\geq 0.25$, large $\geq 0.36$ \\
Sympson's paradox ratio (SPR) & 1.000 & acceptable if $\geq 0.7$, ideally $=1$ \\
R-squared contribution ratio (RSCR) & 1.000 & acceptable if $\geq 0.9$, ideally $=1$ \\
Statistical suppression ratio (SSR) & 1.000 & acceptable if $\geq 0.7$ \\
Nonlinear bivariate causality direction ratio (NLBCDR) & 1.000 & acceptable if $\geq 0.7$ \\
\hline
\end{tabular}

\section{Hypothesis Testing}

The results of hypothesis testing are in the form of path coefficient, P Value and Effect Sizes based on output with WarpPLS 6.0

Table 7

Result of Hypothesis Testing Analysis

\begin{tabular}{|c|c|c|c|c|}
\hline & Path Coefficients $(\beta)$ & P Values & Effect Sizes & Decision \\
\hline $\mathrm{ET} \rightarrow \mathrm{SCA}$ & 0.066 & 0.222 & 0.018 & Not Accepted \\
\hline $\mathrm{ET} \rightarrow \mathrm{EM}$ & 0.124 & 0.074 & 0.042 & Not Accepted \\
\hline $\mathrm{DC} \rightarrow \mathrm{SCA}$ & 0.295 & $<0.001$ & 0.193 & Accepted \\
\hline $\mathrm{DC}->\mathrm{EM}$ & 0.794 & $<0.001$ & 0.657 & Accepted \\
\hline $\mathrm{EM} \rightarrow \mathrm{SCA}$ & 0.417 & $<0.001$ & 0.285 & Accepted \\
\hline $\mathrm{ET} \rightarrow \mathrm{EM} \rightarrow \mathrm{SCA}$ & 0.052 & 0.200 & 0.014 & Not Accepted \\
\hline $\mathrm{DC} \rightarrow \mathrm{EM} \rightarrow \mathrm{SCA}$ & 0.331 & $<0.001$ & 0.217 & Accepted \\
\hline
\end{tabular}

Table 7 shows structural model analysis using effect sizes criteria by Cohen (1988) that stating $\mathrm{R}^{2} 0.02,0.15$, and 0.35 respectively representing small, moderate, and great effect. From the analysis, it was found that ET $(\beta=0.090, \mathrm{p}>0.05)$ insignificantly related to SCA with small effect size $(0.018)$. DC $(\beta=0.295, \mathrm{p}<0.01)$ positively related to SCA with moderate effect size (0.193). ET $(\beta=0.124, \mathrm{p}>0.05)$ insignificantly related to EM with moderate effect size $(0.042)$. DC $(\beta=0.794$, $\mathrm{p}<0.01)$ positively related to EM with great effect size $(0.657)$. EM $(\beta=0.417, \mathrm{p}<0.01)$ positively related to SCA with moderate effect size $(0.285)$.

Additionally, we tested the mediation effect of EM in the relationship of ET-to-SCA and DC-to-SCA. We implemented bootstrap procedure suggested in literature to test the indirect effect, and the result shows that the indirect effect of ET-to-SCA ( $\beta$ $=0.052, \mathrm{p}>0.05)$ was insignificant with small effect size $(0.014)$, while the indirect effect of DC-to-SCA $(\beta=0.331, \mathrm{p}<$ $0.01)$ was significant with moderate effect size $(0.217)$ that shows that there was mediation effect. As suggested by Zhao et al. (2010), the relationship of DC to SCA was significant, similarly DC to EM and EM to SCA were significant, so EM mediated the relationship between DC and SCA with category of partial mediation.

\section{Discussion and Conclusion}

The study developed and tested a model that illustrated the effect of environmental turbulence, dynamic capability, and EM on sustainable competitive advantage. The model was tested using samples of creative economy MSMEs in Indonesia. The research finding shows that higher environmental turbulence did not improve sustainable competitive advantage, on the contrary higher dynamic capability supported the improvement of sustainable competitive advantage. Greater implementation of EM also supported sustainable competitive advantage to be stronger. The result also shows that the relationship between dynamic capability and sustainable competitive advantage was stronger when the company implemented EM more strongly. The finding has important research and managerial implication for development of SMEs.

First, the finding that environmental turbulence did not support higher competitive advantage broadens the idea that internal stability was the best response to dynamic environment (Hannan \& Freeman, 1977). Internal stability in flaring environment enables managers and staff to understand how a successful organization was and what could be expected from them, so they 
made effort to face external challenges rather than fighting with many problems of implementation of internal reformation (Fernandez \& Rainey, 2006). Change of environmental conditions was a certain thing faced by companies but it did not require MSMEs to restructure the organization. Permanent organization with initial regulation would be able to effectively overcome external conditions. MSMEs was in dynamic and complex condition that with small structure form and not fixated in rigid structure and regulation could easily make adjustments and consider various factors (change of market condition and taste, economy, technology, social cultural, policy, and others considered affecting business sustainability) in formulating appropriate strategies and actions to be able to maintain competitive advantage of the company.

Second, the finding that dynamic capability supported higher competitive advantage broadens previous studies stating that MSMEs needed to develop and implement dynamic capability to maintain their competitive advantage in changing and complex external environment (Ambrosini et al., 2009). Changing competition situation and business environment made the strategies of MSMEs not lasting and also made the resources obsolete and irrelevant. MSMEs had to restore their competitive advantage by making adjustments, renewing the aspects of their resources and capability. Dynamic environmental changes required an ability to renew resources and adjust the capability basis. Dynamic capability became a strategy for MSMEs in order to respond to the dynamic and rapidity of environmental shift especially the change of market taste, global economy, and technology by adjusting the capability basis as a part of company activities to be able to improve their competitiveness to achieve competitive advantage.

Third, the finding that the efforts of EM positively related to competitive advantage overall broadens the idea that MSMEs in developing countries we need to maintain the dynamic combination between entrepreneurship spirit and market-oriented activities to improve competitive advantage. The need to integrate EO and MO would help MSMEs adjust their entrepreneurship innovation to customer needs and preference currently and in the future. The conclusion is an extension of previous studies that argue that EO and MO activities individually contribute to performance and competitive advantage (Li \& Liu, 2014; Li \& Atuahene-Gima, 2001). MSMEs that adopt EM process tend to strengthen their competitive position. The result of the study contributes to the existing literature by showing that the implementation of EM offered MSMEs in developing countries a synergy (combination of market competence and entrepreneurial competence) to improve competitive advantage.

Fourth, the finding that EM played a role as mediator in the relationship between dynamic capability and sustainable competitive advantage required MSMEs to take strategic steps by improving their EM ability to obtain more benefits to improve sustainable competitive advantage of the company. It also states that in open economy with innovation here the sources of invention, innovation, and manufacture ability were that quick, the effort to seize and reconfigure the company capability was difficult to be developed and used. Strong efforts for dynamic capability highly aimed to entrepreneurial efforts. The role of partial mediation of EM also gave a justification that the effect of dynamic capability of MSMEs on sustainable competitive advantage would improve when it was mediated by EM. The need to continuously develop the core resources of MSMEs became the support for MSMEs to take strategic steps by implementing and improving EM ability to improve sustainable competitive advantage of the company. EM dominance in improving sustainable competitive advantage confirmed the Resource Advantage (R-A) Theory Hunt \& Morgan (1996) and emphasizes that the source of company advantage comes from sustainable innovation that becomes endogenous competition, creating added value for customers related to entrepreneurial behavior, obtaining additional resources or using more of the existing resources efficiently and effectively. R-A theory accommodates the role of entrepreneurial marketing in development of core competence of MSMEs that is crucial for small enterprises that operate in developing countries where the supporting institutions and business structure are insufficient. Dynamic market environment gave ideal means for companies to implement EO and MO strategies. The result is consistent with literature of strategies and marketing (Bhuian et al., 2005; Jaworski et al., 2000) that shows that strategies involving EO and MO strategies were more effective in dynamic market environment that in static and predictable market. Furthermore, literature of entrepreneurship strengthens the finding that shows that companies need to harmonize their explorative and exploitative ability in dynamic and unpredictable environment (Wiklund \& Shepherd, 2005).

\section{Managerial Implication}

The finding that combination of EO and MO in the concept of EM had positive effect on sustainable competitive advantage overall broadens the idea that the owners/managers of creative economy MSMEs in Indonesia have to be sure that if they consistently develops and grow EM, effectively and efficiently integrating the ability of both EO and MO will give a result of stronger competitive advantage. Because of the mutually complementary role of the two orientations, with one balancing the weakness of the other, the duty of the owners/managers is to ensure that there is no orientation emphasized to set the other one aside. EM is an important construct in achieving sustainable competitive advantage at the same time bridging the relationship of dynamic capability and sustainable competitive advantage. Therefore, the owners/manager of MSMEs have to improve their EM ability especially on how to optimize the use of available and owned resources, focus on customers, and act proactive to be able to improve sustainable competitive advantage. For owners/manager of MSMEs, improvement in terms of the ability to adjust to environmental change, dynamic capability, and EM ability can be said to be successful when the sustainable competitive advantage is improved. The result of the study gives knowledge and understanding for management of MSMEs about the importance of efforts to plan and adjust business strategies to environmental changes, develop dynamic capability, and improve EM ability so the sustainable competitive advantage of the company can be improved. 


\section{Research Limitation and Future Research Agenda}

The research finding shows that the increase of environmental turbulence did not contribute to the improvement of sustainable competitive advantage. The conclusion could not be generalized for other MSMEs in Indonesia that have different characteristics. Therefore, there is a possibility that a study is done by enlarging the area, business scale, or business type of other MSMEs.

In responding to the problems about how to create sustainable competitive advantage, the researcher only focused on three variables with certain dimensions that produce varied contributions to competitive advantage. It is not impossible that actually there are other factors that give great contribution in forming constructs that also have great effect on sustainable competitive advantage. To identify some central themes that govern the harmony of many variables, some alternative methods to learn multivariate configuration have been suggested, such as key variable cluster analysis.

It needs to be underlined that although the study broadens the knowledge about the relationship between the variables and sustainable competitive advantage of the company in the context of MSMEs in developing countries, the result is tentative considering the cross-sectional data characteristics and the source of data used. Collecting data from the second informants or even from secondary data sources can help to improve the confidence on the relationship studied in the study.

\section{References}

Ambrosini, V., Bowman, C., \& Collier, N. (2009). Dynamic capabilities: An exploration of how firms renew their resource base. British Journal of Management, 20, S9-S24.

Arend, R. J., \& Bromiley, P. (2009). Assessing the dynamic capabilities view: spare change, everyone? Strategic Organization, 7(1), 75-90.

Baker, W. E., \& Sinkula, J. M. (2009). The complementary effects of market orientation and entrepreneurial orientation on profitability in small businesses. Journal of Small Business Management, 47(4), 443-464.

Barclay, D., Higgins, C., \& Thompson, R. (1995). The partial least squares (PLS) approach to causal modeling: personal computer adoption and use as an illustration. Technology Studies, 2(2), 285-309.

Barney, J. (1991). Firm Resources and Sustained Competitive Advantage. Journal of Management, 17(1), 99-120.

Barreto, I. (2010). Dynamic Capabilities: A review of past research and an agenda for the future. Journal of Management, $36(1), 256-280$.

Becherer, R. C., Helms, M. M., \& McDonald, J. P. (2012). The Effect of Entrepreneurial Marketing on Outcome Goals in SMEs. New England Journal of Entrepreneurship, 58(1), 871-878.

Bhuian, S. N., Menguc, B., \& Bell, S. J. (2005). Just entrepreneurial enough: the moderating effect of entrepreneurship on the relationship between market orientation and performance. Journal of business research, 58(1), 9-17.

Borch, O. J., \& Madsen, E. L. (2007). Dynamic capabilities facilitating innovative strategies in SMEs. International Journal of Technoentrepreneurship, 1(1), 109.

Bower, J. L., \& Christensen, C. M. (1995). Disruptive Technology: Catching the Wave. Harvard Business Review, 73(1), 4353.

Cadogan, J. W., Kuivalainen, O., \& Sundqvist, S. (2009). Export Market-Oriented Behavior and Export Performance: Quadratic and Moderating Effects under Differing Degrees of Market Dynamism and Internationalization. Journal of International Marketing, 17(4), 71-89.

Carson, D. (1990). Marketing and Small Firms. European Journal of Marketing, 24(11), 8-51. Carson, D. J. (1985). The Evolution of Marketing in Small Firms. European Journal of Marketing, 19(5), 7-16.

Chen, Y. S., Lai, S. B., \& Wen, C. T. (2006). The influence of green innovation performance on corporate advantage in Taiwan. Journal of Business Ethics, 67(4), 331-339.

Chin, W. W. (1998). The partial least squares approach for structural equation modeling. In Methodology for Business and Management. Modern methods for business research. (pp. 295-336). Mahwah, NJ, US: Lawrence Erlbaum Associates Publishers.

Collinson, E., \& Shaw, E. (2001). Entrepreneurial marketing-A historical perspective on development and practice. Management Decision, 39, 761-766.

Crema, M., Verbano, C., \& Venturini, K. (2014). Linking Strategy with Open Innovation and Performance in SMEs. Measuring Business Excellence, 18, 14-27.

D’Aveni, R. A., \& Gunther, R. E. (1995). Hypercompetitive rivalries : competing in highly dynamic environments. Published in 1995 in New York by Free Press Distributed by Simon \& Schuster. Retrieved from https://lib.ugent.be/en/catalog/rug01:001994028

Davis, D., \& Morris, M. (1991). Perceived Environmental Turbulence and Its Effect on. Journal of the Academy of Marketing Science, $19(1), 43-51$.

Dess, G. G., \& Beard, D. W. (1984). Dimensions of Organizational Task Environments. Administrative Science Quarterly, 29(1), 52-73.

Duncan, R. B. (1972). Characteristics of Organizational Environments and Perceived Environmental Uncertainty. Administrative Science Quarterly, 17(3), 313-327. 
Eisenhardt, K. M., \& Brown, S. L. (1998). Competing on the Edge: Strategy as Structured Chaos. Long Range Planning, 31(5), 786-789.

Eisenhardt, K. M., \& Martin, J. A. (2000). Dynamic capabilities: what are they? Strategic Management Journal, 21(10-11), $1105-1121$.

Fernandez, S., \& Rainey, H. G. (2006). Managing Successful Organizational Change in the Public Sector. Public Administration Review, 66(2), 168-176.

González-Benito, Ó., González-Benito, J., \& Muñoz-Gallego, P. A. (2009). Role of entrepreneurship and market orientation in firms' success. European Journal of Marketing, 43(3-4), 500-522.

Grant, R. M. (1996). Toward a knowledge-based view (KBV) theory. Strategic Management Journal, 17(Winter), $109-122$.

Hakala, H. (2011). Strategic Orientations in Management Literature: Three Approaches to Understanding the Interaction between Market, Technology, Entrepreneurial and. 13, 199-217.

Hamel, G., Doz, Y. L., \& Prahalad, C. K. (1989). Collaborate with Your Competitors - and Win: Business Source. Harvard Business Review, 67(1), 133-139.

Hannan, M. T., \& Freeman, J. (1977). The Population Ecology of Organizations. American Journal of Sociology, 82(5), 929964.

Helfat, C. E., \& Peteraf, M. A. (2009). Understanding dynamic capabilities: progress along a developmental path. Strategic Organization, 7(1), 91-102.

Helfat, C. E., \& Winter, S. G. (2011). Untangling Dynamic and Operational Capabilities : Strategy for the Never-Changing World. Strategic Management Journal, 32(11), 1243-1250.

Hitt, M. a., Keats, B. W., \& DeMarie, S. M. (1998). Navigating in the new competitive landscape: Building strategic flexibility and competitive advantage in the 21 st century. Academy of Management Perspectives, 12(4), $22-42$.

Hoskisson, R. E., Eden, L., Lau, C. M., \& Wright, M. (2000). Strategy in emerging economies. Academy of Management Journal, 43(3), 249-267.

Hult, G. T. M., \& Ketchen, D. J. (2001). Does market orientation matter?: A test of the relationship between positional advantage and performance. Strategic Management Journal, 22(9), 899-906.

Hunt, S. D., \& Morgan, R. M. (1996). The Resource-Advantage Theory of Competition: Dynamics, Path Dependencies , and. Journat of Marketing, 60(October), 107-114.

Jaworski, B., Kohli, A. K., \& Sahay, A. (2000). Market-driven versus driving markets. Journal of the Academy of Marketing Science, 28(1), 45-54.

Jones, R., \& Rowley, J. (2011). Entrepreneurial marketing in small businesses: A conceptual exploration. International Small Business Journal, 29(1), 25-36.

Kam-Sing Wong, S. (2014). Impacts of environmental turbulence on entrepreneurial orientation and new product success. European Journal of Innovation Management, 17(2), 229-249.

Ketchen, D. J., Jr, Thomas, J. B., \& Snow, C. C. (1993). Organizational configurations and performance: A comparison of theoretical approaches. Academy of Management Journal, 36(6), 1278 . Retrieved from http://search.ebscohost.com/login.aspx?direct=true\&db=buh\&AN=9410210630\&site=ehost-live

Huang, S. K., \& Wang, Y. L. (2011). Entrepreneurial orientation, learning orientation, and innovation in small and medium enterprises. Procedia-Social and Behavioral Sciences, 24, 563-570.

Kirca, A. H., Jayachandran, S., \& Bearden, W. O. (2005). Market Orientation : A Meta-Analytic Review and Assessment of Its Antecedents and Impact on. Journal of Marketing, 69(April), 24-41.

Knight, G. A., \& Kim, D. (2009). International business competence and the contemporary firm. Journal of International Business Studies, 40(2), 255-273.

Kocak, A., \& Abimbola, T. (2009). The effects of entrepreneurial marketing on born global performance. International Marketing Review, 26(4), 439-452.

Kohli, A. K., \& Jaworski, B. J. (1990). Market Orientation: The The Construct, Research Propositions, and Managerial Implications. Journal of Marketing, 54(April), 1-18.

Kraus, S., Harms, R., \& Fink, M. (2009). Entrepreneurial marketing: moving beyond marketing in new ventures. International Journal of Entrepreneurship and Innovation Management, 11(1), 19.

Kropp, F., Lindsay, N. J., \& Shoham, A. (2006). Entrepreneurial, market, and learning orientations and international entrepreneurial business venture performance in South African firms. International Marketing Review, 23(5), 504-523.

Kuivalainen, O., Sundqvist, S., Puumalainen, K., \& Cadogan, J. W. (2009). The Effect of Environmental Turbulence and Leader Characteristics on International Performance: Are Knowledge-Based Firms Different? Canadian Journal of Administrative Sciences / Revue Canadienne Des Sciences de l'Administration, 21(1), 35-50.

Li, D. yuan, \& Liu, J. (2014). Dynamic capabilities, environmental dynamism, and competitive advantage: Evidence from China. Journal of Business Research, 67(1), 2793-2799.

Li, H., \& Atuahene-Gima, K. (2001b). Product innovation strategy and the performance of new technology ventures in China. Academy of Management Journal, 44(6), 1123-1134.

Lin, X., \& Germain, R. (2003). Organizational structure, context, customer orientation, and performance: Lessons from chinese state-owned enterprises. Strategic Management Journal, 24(11), 1131-1151.

Lumpkin, G. T., \& Dess, G. G. (1996). Clarifying the entrepreneurial orientation construct and linking it to performance. Academy of Management Review, 21(1), 135-172. 
Lumpkin, G. T., \& Dess, G. G. (2001). Linking two dimensions of entrepreneurial orientation to firm performance: The moderating role of environment and industry life cycle. Journal of Business Venturing, 16, 429-451.

Meyer, A. D., Tsui, A. S., \& Hinings, C. R. (1993). Configurational Approaches to Organizational Analysis. The Academy of Management Journal, 36(6), 1175-1195.

Miles, M. (1991). The Relationship Between Marketing Orientation and Entrepreneurial Orientation. Entrepreneurship: Theory and Practice, 15, 49-65.

Miles, M. P., \& Darroch, J. (2006). Large firms, entrepreneurial marketing processes, and the cycle of competitive advantage. European Journal of Marketing, 40(5-6), 485-501.

Mintzberg, H. (1984). Power In and Around Organizations 1983, Englewood Cliffs, N.J.: Prentice-Hall. 700 pages. Organization Studies, 5(4), 377-378.

Morris, M. H., Schindehutte, M., \& LaForge, R. W. (2002). Entrepreneurial Marketing: A Construct for Integrating Emerging Entrepreneurship and Marketing Perspectives. Journal of Marketing Theory and Practice, 10(4), 1-19.

Mort, G. S., Weerawardena, J., \& Liesch, P. (2012). Advancing entrepreneurial marketing: Evidence from born global firms. European Journal of Marketing, 46(3-4), 542-561.

Murray, J. A. (1981). Marketing is home for the entrepreneurial process. Industrial Marketing Management, 10(2), 93-99.

Murray, J. Y., Gao, G. Y., \& Kotabe, M. (2011). Market orientation and performance of export ventures: The process through marketing capabilities and competitive advantages. Journal of the Academy of Marketing Science, 39(2), $252-269$.

Parida, V. (2008). Small Firm Capabilities for Competitiveness. Lulea University of Technology.

Porter, M. E. (1990). The Competitive Advantage of Nations Harvard Business Review. Harvard Business Review, 91.

Power, B., \& Reid, G. C. (2005). Flexibility, Firm-Specific Turbulence and the Performance of the Long-lived Small Firm. Review of Industrial Organization, 26(4), 415-443. -5

Prahalad, C. K., \& Hamel, G. (1990). The Core Competence of the Corporation. Harvard Business Review, may-june, 1-17.

Rauch, A., Wiklund, J., \& Frese, M. (2009). E T\& P Orientation and Business Performance : An Assessment of Past Research and the Future.

Gordon, S. (2000). Convergence Versus Strategic Reorientation: The Antecedents of Fast-paced Organizational Change. Journal of Management, 26, 911-945.

Short, J. C., Payne, G. T., \& Ketchen, D. J. (2008). Research on organizational configurations: Past accomplishments and future challenges. Journal of Management, 34(6), 1053-1079.

Stefano, G. Di, Peteraf, M. A., \& Verona, G. (2010). Dynamic capabilities deconstructed : a bibliographic investigation into the origins, development, and future directions of the research domain. Industrial and Corporate Change, 19(4), 11871204.

Stokes, D. (2000). Selected papers from the Academy of Marketing Conference Entrepreneurial marketing: a conceptualisation from qualitative research. Qualitative Market Research: An International Journal, 3(1), 47-54.

Tambunan, T. T. H. (2008). Size of Cooperative and SME's Competitiveness. National Development Planning Agency, 130.

Tambunan, T. T. H. (2010). Socio-Economic Impacts of the Global Economic Crisis: The Indonesian Story. Afro Asian Journal of Social Sciences.

Tan, J. J., \& Litschert, R. J. (1994). Environment-strategy relationship and its performance implications: An empirical study of Chinese electronics industry. Strategic Management Journal, 15(1), 1-20.

Teece, D. J. (2007). Explicating Dynamic Capabilities: The Nature And Microfoundations Of ( Sustainable ) Enterprise Performance. Strategic Management Journal 28(August), 1319-1350.

Teece, D. J. (2016). Dynamic capabilities and entrepreneurial management in large organizations: Toward a theory of the (entrepreneurial) firm. European Economic Review, 86, 202-216.

Teece, D. J., Gary, P., \& Shuen, A. (1997). Dynamic Capabilites and Strategic Management. Strategic Management Journal, 18(April 1991), 509-533.

Teece, D. J., Rumelt, R., Dosi, G., \& Winter, S. (1994). Dynamic capabilities and strategic management. Journal of Economic Behavior \& Organization, 23, 1-30.

Teece, D., Pisano, G., \& Shuen, A. (1997). Dynamic capabilities and strategic management. Strategic Management Journal, 18(7), 509-533.

Thomas, L. C., Painbéni, S., \& Barton, H. (2013). Entrepreneurial marketing within the French wine industry. International Journal of Entrepreneurial Behaviour and Research, 19(2), 238-260.

Volberda, H., \& Bruggen, G. (1997). Environmental turbulence: A look into its dimensionality. Dynamiek in Organisatie En Bedrijfsvoering, (January 1997), 137-146. Retrieved from

Volberda, H. W., \& van Bruggen, G. H. (1997). Environmental Turbulence: A Look into its Dimensionality. Nederlandse Organisatie Voor Bedrijfskundig Onderzoek, (January 1997), 137-145.

Wang, C. L., \& Ahmed, P. K. (2007). Dynamic capabilities: A review and research agenda. International Journal of Management Reviews, 9, 31-51.

Ward, P., \& Duray, R. (2000). Manufacturing strategy in contrext: environment, competitive strategy and manufacturing strategy. Journal of Operations Management, 18, 123-138.

Ward, P. T., Duray, R., Keong Leong, G., \& Sum, C. C. (1995). Business environment, operations strategy, and performance: An empirical study of Singapore manufacturers. Journal of Operations Management, 13(2), 99-115. 
Wiklund, J., \& Shepherd, D. (2005). Entrepreneurial orientation and small business performance: a configurational approach. Journal of Business Venturing, 20, 71-91.

Wright, M., Filatotchev, I., Hoskisson, R. E., \& Peng, M. W. (2005). Strategy research in emerging economies: Challenging the conventional wisdom. Journal of Management Studies, Vol. 42, pp. 1-33.

Zahra, S. A., \& Garvis, D. M. (2000). International corporate entrepreneurship and firm performance: The moderating effect of international environmental hostility. Journal of Business Venturing, 15(5), 469-492.

Zott, C. (2003). Dynamic capabilities and the emergence of intraindustry differential firm performance: Insights from a simulation study. Strategic Management Journal, 24(2), 97-125.

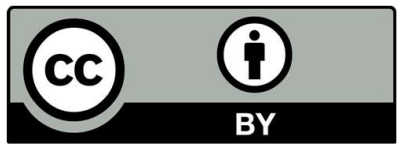

(C) 2020 by the authors; licensee Growing Science, Canada. This is an open access article distributed under the terms and conditions of the Creative Commons Attribution (CCBY) license (http://creativecommons.org/licenses/by/4.0/). 